Egypt. Acad. J. biolog. Sci., 3(1):5-15 (2011)

Email: egyptianacademic@yahoo.com

Received: 1/2/2011
C. Physiology \& Molecular Biology

ISSN: 2090-0767

www.eajbs.eg.net

\title{
Physiological studies on the effect of a bradykinin potentiating factor (BPF) isolated from scorpion venom on the burnt skin of alloxan-induced diabetic Guinea pigs.
}

\author{
Abd-Elraheim A. Elshater, Muhammad M. A. Salman and \\ Asmaa F. Abd-Elhady \\ Department of Zoology, Faculty of Science, South Valley University, Qena, Egypt
}

\begin{abstract}
It is well known that, Wound healing in the diabetes is enormous, growing problem and having cost Medicaid. Therefore, this study produces an exciting prospect, to improve diabetic burn healing, and evaluates the ability of a bradykinin potentiating factor (BPF) isolated from scorpion venom (Buthus occitanus) in treatment of burns in diabetic male Guinea pigs. Male Guinea pigs of approximate (550 g body weight each) were divided into five groups. In the normal group; Guinea pigs were interaperitoneally (i.p) injected with $100 \mu \mathrm{L}$ saline solution. The second, served as control group which were injected with $100 \mu \mathrm{L}$ saline solution then standard burns were obtained on the dorsal skin. The $3^{\text {rd }}, 4^{\text {th }}$ and $5^{\text {th }}$ groups were i.p. injected with $(750 \mathrm{mg} / \mathrm{kg}$, body weight) with a single dose of Alloxan, then standard burns were obtained, after that the $4^{\text {th }}$ group was treated by BPF in $100 \mu \mathrm{L}$ saline solutions $\left(1 \mu \mathrm{g} / \mathrm{gm}\right.$. b. w.) topically and the $5^{\text {th }}$ group treated with BPF $(1 \mu \mathrm{g} / \mathrm{gm} . \mathrm{b}$. w. $)$ topically and interperitonialy $(1 \mu \mathrm{g} / \mathrm{gm}$. b. w. twice a week). Every group contains 20 animals and sacrificed at 15 and 30 days post-treatment by BPF (10 animals per each). The results are recorded after monitoring the $\mathrm{CBC}$ including (RBCs, WBCs, platelets, $\mathrm{Hb}$ content and HCT percentage), lipid profile including (total cholesterol (TC), triglyceride (TGs), high density lipoprotein (HDL), low density lipoprotein (LDL) and very low density lipoprotein (VLDL)) and the skin antioxidant status (catalase activity (CAT) and superoxide dismutase (SOD) and serum nitric oxide (NO) beside malondialdehyde (MDA) concentration were also monitored during the study compared to normal animals. Also serum glucose level was monitored. The recorded results declared that, the treatment with BPF has shown an ameliorative effect on burn healing in diabetic animals. These observations and investigations were the pacemaker for the hypothesized ameliorating activity of BPF in the present study.
\end{abstract}

Keywords: scorpion venom, Buthus occitanus, BPF, burnt wound healing, diabetes and Guinea pigs.

INTRODUCTION:

Diabetes mellitus DM is a group of metabolic disorders with one common manifestation: hyperglycemia associated with defects in insulin secretion, action or both. It is well known that diabetes mellitus results in many complications to the individual, foot ulceration taking the greatest toll, which will be focused in this study. Several laboratory rodent models (Buschard, 1996) as well as non-rodent species (Sun et al., 1996) are available for studying both types of diabetes. The development of the syndrome in these models is either spontaneous (Weiss et al., 2005), induced by chemical agents such as alloxan or streptozotocin (Portha et al., 1989), or caused by a virus infection (Filippi and Von Herrath, 2005).

A variety of factors including tissue damage, allergic reactions, viral infection and other inflammatory events activate a series of proteolytic reactions that generate bradykinin and kallidin in the tissues (Wachtfogel et al., 1998). 
The nonapeptide bradykinin has a wide range of biological effects on a number of different tissues and organs. Bradykinin is most known for its potent vasodilatory effect. It is also involved in smooth muscle contraction, regulation of vascular permeability, pain induction, cell proliferation and development of pathological states such as inflammation (Hall, 1992). The bradykinin potentiating factor BPF extracted from Leiurus quinquestriatus venom was shown to enhance the cellular growth of the uterus and development of the ovarian follicle in female mice (Abdel Raheim et al., 1995). Similarly, injection of this BPF enhanced spermatogenesis. Moreover, Salman (2002) declared that injection of $\mathrm{BPF}$ in sublethally-irradiated and nonirradiated Guinea pigs accelerated the generation of thymus and spleen cellularity without noticeable toxic effects in non-irradiated control animals. Nassar et al., 1990 and Abd-El-Rahim, 1990 stated that, BPF of Buthus occitanus venom showed growth factorlike activity.

It is worth to mention that, the recent researches recorded that there is a relation between bradykinin and oxidative stress, kinin may attenuate inflammatory responses and renal fibrosis by inhibiting oxidative stress and mitogen-activated protein kinase (MAPK) activation (Chao et al., 2007), therefore, oxidative stress parameters ( MDA, CAT, SOD and Nitric oxide) were monitored during our study. In addition this study monitors lipid profile (cholesterol, HDL, LDL, vLDL and triglycerides) and serum glucose because alloxan causes diabetes which leads to a massive reduction in insulin release by the destruction of $\beta$-cells of the islets of langerhans, thereby, inducing hyperglycaemia and hyperlipidemia as consequent (Grover et al., 2000 and Sharma et al., 2010).

\section{MATERIALS AND METHODS}

Chemicals: Alloxan monohydrate was obtained from Sigma Chemicals Company, Cairo, Egypt. Kits of glucose, cholesterol, triglycerides, HDL, LDL, MDA, SOD, NO and catalase were obtained from Biodiagnostic Company, Cairo, Egypt.

\section{Isolation of Bradykinin Potentiating factor (BPF):}

Firstly the crude venom was collected from scorpion, Buthus occitanus gathered from the Aswan area. The scorpions were milked in the physiology laboratory at the Faculty of Science in Qena, South Valley University with a specific device using electrical shocks $(6$ volts $)$ at the articular membrane of the telson. The collected droplets were received into a clean dry glass container. The venom was lyophilized and freeze dried after which it was kept at $-10{ }^{\circ} \mathrm{C}$ (in the dark) until it was used. . The venom fraction (BPF) separated from Buthus occitanus was isolated, purified and detected according to the method of (Ferreira, 1965).

Animals: Adult Guinea pigs of approximate (550 g body weight each) were selected. The animals were housed in the Animal House of the Faculty of science, South Valley University, Qena, Egypt, for two weeks under natural day and night periods and supplied with a balanced diet and water ad libitum. Animals were divided into four groups each was sacrificed every 15 and/or 30 days as the following:

Group 1 (normal group): Each of 20 animals injected with $(100 \mathrm{ml} / \mathrm{kg}$ body weight) of saline solution intraprotinially. This group served as normal group.

Group 2 (normal burned group): Each of 20 animals injected i.p. with (100 $\mathrm{ml} / \mathrm{kg}$ body weight) saline solution then standard burns were obtained on the dorsal skin without treatment. Then they were sacrificed after 15 and 30 days.

Group 3 (diabetic burned group): Each of 20 animals injected i.p. with (750 
$\mathrm{mg} / \mathrm{kg}$ ), alloxan to induce diabetes then standard bruns of skin were obtained without treatment. Then they were sacrificed after 15 and 30 days.

Group4 (BPF topically treated group): Each of 20 animals injected i.p. with alloxan to induce diabetes then standard bruns of skin are obtained. This group was treated topically with BPF daily. Then 10 animals were sacrificed after 15 (i.e., after 15 doses of topical treatment). The other 10 animals were sacrificed after 30 days (i.e., after 30 doses of topical treatment).

Group 5 (BPF top. and i.p. treated group): Each of 20 animals injected i.p. with alloxan to induce diabetes then standard bruns of skin are obtained. They were treated topically with BPF daily and i.p. with BPF also twice a week. After this 10 animals were sacrificed after 15 (i.e., after having 15 doses of topical treatment and 4 i.p. doses of BPF). The other 10 animals were sacrificed after 30 days (i.e., after having 30 doses of topical treatment and 8 i.p. doses of BPF)

\section{Collection of samples:}

12 hrs Fasting animals were sacrificed. Peripheral blood was divided into two portions (the first portion was used as whole blood for complete blood count (CBC), the second was used for separation of serum) also a part of the skin tissue was taken to prepare tissue homogenate as the following:

\section{Whole blood collection:}

Whole blood samples were received in clean EDTA tubes. These fresh samples were directly used in RBCs. count, WBCs count, platelets count, hematocrit and HB content.

\section{Serum preparation:}

Blood samples in this case were collected in clean and dry tubes. Then the blood was let to clot at room temperature. After an hour, serum was separated by centrifugation for 30 minutes at 3000 rpm. Then collected in labeled
Epindroff's tubes and stored at $-20 \mathrm{C}$ for biochemical analysis.

\section{Skin Tissue Homogenate preparation:}

Skin tissue was perfused with PBS (phosphate buffered saline) solution, $\mathrm{pH}$ 7.4 containing $0.16 \mathrm{mg} / \mathrm{ml}$ heparin to remove any red blood cells and clots. Tissue then was homogenized in 5_10 ml cold buffer (i.e. $50 \mathrm{Mm}$ potassium phosphate, $\mathrm{pH} 7.4,1 \mathrm{mM}$ EDTA and 1 $\mathrm{ml} / \mathrm{L}$ Triton X-100) per gram tissue. After this the sample was centrifuged at $4,000 \mathrm{rpm}$ for 15 minutes at 4 C. Finally the supernatant was removed for assay and freeze at $-80 \mathrm{C}$ (Nishikimi et al., 1972).

\section{Biochemical parameter of whole blood, serum and skin tissue:}

Biochemical parameters; Serum glucose was determined with an enzymatic colorimetric method. Lipid profile was estimated (Trivedi et al., 2004) by enzymatic method using reagent kit obtained from (Bio-diagnostic Company, Cairo, Egypt) and was analyzed according to the reported methods. Malondialdehyde MDA (Ohkawa, et al., 1979), Catalase CAT (Fossati et al., 1980) and super oxide dismutase SOD (Nishikimi et al., 1972), were analyzed also using available kits from (Bio-diagnostic Company, Cairo, Egypt) according the reported methods. Blood cell counts, hematocrit or packed cell volume (PCV) and hemoglobin $(\mathrm{Hb})$ content were determined using Celltac $\alpha$ apparatus from NIHON KOHDEN (MEK-6410K).

\section{Statistical analysis:}

The variability degree of results was expressed as means \pm standard deviation of means (Mean \pm S.D). The significance of the difference between samples was determined using Graph Pad Prism 03n software, where appropriate. The difference was regarded significant at $\mathrm{P}<0.05$. 


\section{RESULTS}

Effect of BPF on serum glucose level of the diabetic burned Guinea pigs:

The recorded results in tables (1) showed that glucose level in diabetic burned male Guinea Pigs after 15 days was significantly increased $(\mathrm{p}<0.05)$ when compared with normal and normal burned groups.

With time proceeding (i.e. after 30 days) a highly significant increase $(\mathrm{p}<$
0.01) occurred. With topical treatment there was a non-significant decrease in glucose level after 15 or 30 days when compared with those of non treated groups under normal conditions. In the case of both 15 and 30 days of topical and i.p. BPF treatment a significant decrease $(\mathrm{P}<0.05)$ in glucose level was observed in comparing with diabetic burned group.

Table 1: Effect of interpretonially (i.p.) and/or topically treatment with bradykinin potentiating factor (BPF) $1 \mu \mathrm{g} / \mathrm{gm}$ isolated from scorpion venom Buthus occitanus within 15 and 30 days on serum glucose of burned skin of alloxan-induced diabetic Guinea Pigs:

\begin{tabular}{|c|c|c|}
\hline \multirow{2}{*}{ Groups } & Glucose level after 15 days & Glucose level after 30 days \\
\cline { 2 - 3 } & Mean \pm S. D. & Mean \pm S. D. \\
\hline Normal & $90.0 \pm 5.2$ & $95.0 \pm 6.0$ \\
\hline Normal Burned & $98.0 \pm 6.0$ & $88.0 \pm 7.0$ \\
\hline Diabetic burned (control) & $260.0^{+\mathrm{a}} \pm 9.0$ & $337.0^{++\mathrm{a}} \pm 8.0$ \\
\hline Top. BPF (Treatment) & $236.0 \pm 9.0$ & $248.0 \pm 5.0$ \\
\hline Top. + i.p. BPF (Treatment) & $220.0^{-\mathrm{b}} \pm 9.0$ & $218.0^{-\mathrm{b}} \pm 10.0$ \\
\hline
\end{tabular}

Results are expressed as mean \pm S.D. of 10 animals.

$+\mathrm{a}=$ significantly increased from the normal at $\mathrm{p}<0.05$.

$++\mathrm{a}=$ highly significantly increased from the normal at $\mathrm{p}<0.01$.

$-\mathrm{b}=$ significantly decreased from diabetic burned group at $\mathrm{p}<0.05$.

$-\mathrm{b}=$ highly significant decreased from the normal at $\mathrm{p}<0.01$

Effect of BPF on complete blood count (CBC) of the diabetic burned Guinea pigs:

As recorded in Table (2), diabetic burned group showed a significant decrease in RBCs, Hb, HCT and platelets after 15 days and a highly significant decrease after 30 days of the same parameters. In contrast, WBCs count was significantly increased after 15 days and highly significant increased after 30 days. After 15 days of topical treatment, there was neither a significant increase in RBCs, Hb, HCT and Platelets nor a significant decrease in WBCs when compared with control group. While in the case of topical and i.p. treatment (after 15 days) there was a significant increase in RBCs, Hb, HCT and Platelets while WBCs recorded a significant decrease.

Also in comparing animals with diabetic burned group the RBCs, $\mathrm{Hb}$, HCT and Platelets showed a significant increase after 30 days of topical treatment with BPF in and a corresponding significant decrease in WBCs. Similarly a highly significant increase was observed in RBCs, Hb, HCT and Platelets and a corresponding highly significant decrease in WBCs. 
Table 2: Complete blood count (RBCs, Hb, WBCs, and HCT) after 15 and 30 days in topically treatment with BPF and intraperitoneally + topically treatment with BPF groups in comparison with normal and control groups

\begin{tabular}{|c|c|c|c|c|c|}
\hline \multirow[t]{2}{*}{ Groups } & $\begin{array}{c}\text { RBCs } \\
\mathrm{X} 10^{12} / 1 \\
\end{array}$ & $\begin{array}{c}\mathbf{H b \%} \\
\mathrm{g} / \mathrm{dl} \\
\end{array}$ & $\begin{array}{r}\text { WBCs } \\
\times 10^{9} / 1 \\
\end{array}$ & $\begin{array}{c}\text { Platelets } \\
\text { x } 10^{9} / 1 \\
\end{array}$ & $\begin{array}{c}\text { HCT } \\
\% \\
\end{array}$ \\
\hline & Mean \pm S. D. & Mean \pm S. D. & Mean \pm S. D. & Mean \pm S. D. & Mean \pm S.D. \\
\hline \multicolumn{6}{|c|}{ After 15 days } \\
\hline Normal & $6.52 \pm 0.09$ & $13.1 \pm 0.36$ & $7.7 \pm 0.24$ & $392 \pm 9.0$ & $39.5 \pm 1.18$ \\
\hline Normal burned & $5.90 \pm 0.12$ & $11.1 \pm 0.29$ & $10.7^{+\mathrm{a}} \pm 0.37$ & $388 \pm 9.0$ & $37.3 \pm 1.11$ \\
\hline $\begin{array}{l}\text { Diabetic burned } \\
\text { (control) }\end{array}$ & $4.22^{-\mathrm{a}} \pm 0.14$ & $8.3^{-\mathrm{a}} \pm 0.23$ & $19.3^{-a} \pm 0.46$ & $301^{-\mathrm{a}} \pm 7.0$ & $28.3^{-\mathrm{a}} \pm 0.91$ \\
\hline $\begin{array}{c}\text { Topical BPF } \\
\text { (Treatment) }\end{array}$ & $4.94 \pm 0.18$ & $9.2 \pm 0.34$ & $14.5 \pm 0.31$ & $327 \pm 7.0$ & $34.4 \pm 0.76$ \\
\hline $\begin{array}{c}\text { Topical + i.p. BPF } \\
\text { (Treatment) }\end{array}$ & $5.91^{+b} \pm 0.12$ & $10.7^{+b} \pm 0.32$ & $11.5^{-\mathrm{b}} \pm 0.36$ & $331^{+\mathrm{b}} \pm 10.0$ & $36.5^{+\mathbf{b}} \pm 1.13$ \\
\hline \multicolumn{6}{|c|}{ After 30 days } \\
\hline Normal & $6.55 \pm 0.11$ & $14.2 \pm 0.34$ & $7.9 \pm 0.26$ & $382 \pm 7.0$ & $42.1 \pm 1.16$ \\
\hline Normal burned & $5.76 \pm 0.17$ & $11.0 \pm 0.31$ & $12.6^{+a} \pm 0.34$ & $391 \pm 8.0$ & $38.0 \pm 1.04$ \\
\hline $\begin{array}{c}\text { Diabetic burns } \\
\text { (control) }\end{array}$ & $3.75^{-\mathrm{a}} \pm 0.24$ & $7.0^{-\mathrm{a}} \pm 0.23$ & $21.3^{-\mathrm{a}} \pm 0.76$ & $283^{-\mathrm{a}} \pm 9.0$ & $22.2^{--\mathrm{a}} \pm 1.08$ \\
\hline $\begin{array}{c}\text { Topical BPF } \\
\text { (Treatment) }\end{array}$ & $5.28^{+b} \pm 0.12$ & $10.6^{+b} \pm 0.28$ & $13.5^{+b} \pm 0.33$ & $340^{+b} \pm 10.0$ & $36.2^{+\mathbf{b}} \pm 1.06$ \\
\hline $\begin{array}{l}\text { Topical + i.p. BPF } \\
\text { (Treatment) }\end{array}$ & $6.34^{++b} \pm 0.11$ & $13.3^{++\mathbf{b}} \pm 0.34$ & $9.5^{-\mathbf{b}} \pm 0.33$ & $387^{++\mathbf{b}} \pm 11.0$ & $38.2^{++\mathbf{b}} \pm 0.97$ \\
\hline
\end{tabular}

Results are expressed as mean \pm S.D. of 10 animals.

$+\mathrm{a}=$ significantly increased from normal at $\mathrm{p}<0.05$

$++\mathrm{a}=$ highly significant increased from normal at $\mathrm{p}<0.01$

-a $=$ significantly decreased from normal at $\mathrm{p}<0.05$

--a = highly significant decreased from normal at $\mathrm{p}<0.01$

$+\mathrm{b}=$ significantly increased from diabetic burned (control) at $\mathrm{p}<0.05$

$++\mathrm{b}=$ highly significant increased from diabetic burned (control) at $\mathrm{p}<0.01$

$-\mathrm{b}=$ significantly decreased from diabetic burned (control) at $\mathrm{p}<0.05$

$--\mathrm{b}=$ highly significant decreased from diabetic burned (control) at $\mathrm{p}<0.01$

Effect of BPF isolated from scorpion venom on antioxidant status and MDA concentration in burnt skin tissue of diabetic Guinea pigs:

Effect of BPF on antioxidant parameters catalase (CAT), superoxide dismutase (SOD) and nitric oxide (NO):

The activity of CAT and SOD in skin tissue of diabetic burned group after 15 days were significantly decreased $(\mathrm{P}<0.05)$ as recorded in table 3 and highly significant decreased $(\mathrm{p}<0.01)$ after 30 days. In addition the concentration of serum NO in burnt diabetic group was significantly decreased $(\mathrm{P}<0.05)$ and a highly significant decreased $(p<0.01)$ as shown in Table 3.
There was a significant increase $(\mathrm{P}<0.05)$ in CAT, SOD and serum NO of diabetic burnt group after 30 days of treatment with BPF topically. The treatment with BPF topically and interperitonialy showed a significant increase $(\mathrm{P}<0.05)$ in $\mathrm{NO}, \mathrm{SOD}$ activity and CAT activity after 15 days as recorded in table 3 and highly significant increase $(\mathrm{p}<0.01)$ after 30 days, as shown in Table 3.

\section{Effect of BPF malondialdehyde level (MDA):}

The level of MDA in skin tissue of diabetic burned group was significantly increased $(\mathrm{P}<0.05)$ as recorded in table 3 (after 15 days) and a highly significant increased $(p<0.01)$ after 30 days. 
In contrast, the treatment with BPF topically recorded a significant decrease $(\mathrm{P}<0.05)$ after 30 days as shown in table 3. While treatment with BPF topically and interperitonially of burnt diabetic animals, showed a decrease $(\mathrm{P}<0.05)$ and highly significant decrease $(\mathrm{p}<0.01)$ after 30 days, as recorded in Table 3.

Table 3: Effect of interpretonially (i.p.) and/or topically treatment with bradykinin potentiating factor (BPF) $1 \mu \mathrm{g} / \mathrm{gm}$ isolated from scorpion venom Buthus occitanus within 15 and 30 days on MDA, CAT, SOD and NO of burned skin of alloxan-induced diabetic Guinea Pigs.

\begin{tabular}{|c|c|c|c|c|}
\hline \multirow{2}{*}{ Groups } & $\begin{array}{c}\text { MDA } \\
\mathrm{Nmol} / \mathrm{g} \\
\end{array}$ & $\begin{array}{c}\text { CAT } \\
\text { U/g protein }\end{array}$ & $\begin{array}{c}\text { SOD } \\
\mathrm{u} / \mathrm{g} \text { protein }\end{array}$ & $\begin{array}{c}\text { NO } \\
\mu \mathrm{mol} / \mathrm{L}\end{array}$ \\
\hline & Mean \pm S.D. & Mean \pm S. D. & Mean \pm S. D. & Mean \pm S. D \\
\hline \multicolumn{5}{|c|}{ After 15 days } \\
\hline Normal & $179 \pm 4.99$ & $3.19 \pm 0.13$ & $79.19 \pm 1.67$ & $44.8 \pm 1.08$ \\
\hline Normal burned & $200.5 \pm 7.24$ & $2.99 \pm 0.06$ & $70,13 \pm 1.24$ & $37,97 \pm 0.87$ \\
\hline $\begin{array}{l}\text { Diabetic burned } \\
\text { (control) }\end{array}$ & $262.5^{+a} \pm 4.80$ & $1.92^{-\mathrm{a}} \pm 0.07$ & $33.49^{-a} \pm 1.76$ & $18.47^{-\mathrm{a}} \pm 0.95$ \\
\hline $\begin{array}{c}\text { Topical BPF } \\
\text { (Treatment) }\end{array}$ & $227.4 \pm 6.11$ & $2.01 \pm 0.09$ & $41.89 \pm 1.50$ & $24.89 \pm 1.00$ \\
\hline $\begin{array}{l}\text { Topical + i.p. BPF } \\
\text { (Treatment) }\end{array}$ & $209.2^{-\mathrm{b}} \pm 8.79$ & $2.35^{+b} \pm 0.12$ & $51.75^{+b} \pm 2.12$ & $32.16^{+\mathbf{b}} \pm 1.01$ \\
\hline \multicolumn{5}{|c|}{ After 30 days } \\
\hline Normal & $184.0 \pm 6.01$ & $3.39 \pm 0.10$ & $84.02 \pm 2.66$ & $41.08 \pm 0.89$ \\
\hline Normal burned & $207.6 \pm 11.55$ & $2.77 \pm 0.08$ & $69.46 \pm 1.10$ & $37.12 \pm 1.01$ \\
\hline $\begin{array}{c}\text { Diabetic burns } \\
\text { (control) }\end{array}$ & $400.9^{++a} \pm 7.54$ & $0.91^{--\mathrm{a}} \pm 0.11$ & $18.59^{-\mathrm{a}} \pm 1.85$ & $12.02^{-\mathrm{a}} \pm 1.00$ \\
\hline $\begin{array}{c}\text { Topical BPF } \\
\text { (Treatment) }\end{array}$ & $203.7^{-\mathrm{b}} \pm 6.94$ & $2.43^{+b} \pm 0.08$ & $56.31^{+b} \pm 1.80$ & $31.10^{+\mathbf{b}} \pm 1.04$ \\
\hline $\begin{array}{c}\text { Topical + i.p. BPF } \\
\text { (Treatment) }\end{array}$ & $191.0^{-\mathbf{b}} \pm 9.88$ & $3.17^{++\mathbf{b}} \pm 0.10$ & $70.61^{++b} \pm 1.92$ & $37.92^{++\mathbf{b}} \pm 1.03$ \\
\hline
\end{tabular}

Results are expressed as mean \pm S.D. of 10 animals.

$+\mathrm{a}=$ significantly increased from normal at $\mathrm{p}<0.05$

$++\mathrm{a}=$ highly significant increased from normal at $\mathrm{p}<0.01$

$-\mathrm{a}=$ significantly decreased from normal at $\mathrm{p}<0.05$

$--\mathrm{a}=$ highly significant decreased from normal at $\mathrm{p}<0.01$

$+\mathrm{b}=$ significantly increased from diabetic burned (control) at $\mathrm{p}<0.05$

$++b=$ highly significant increased from diabetic burned (control) at $\mathrm{p}<0.01$

$-\mathrm{b}=$ significantly decreased from diabetic burned (control) at $\mathrm{p}<0.05$

$--\mathrm{b}=$ highly significant decreased from diabetic burned (control) at $\mathrm{p}<0.01$

Effect of BPF isolated from scorpion venom on serum lipid profile diabetic burned Guinea Pigs:

The recorded results in Tables (4) showed that TGs, T. Cholesterol, LDL and vLDL level in diabetic burned male Guinea pigs after 15 days increased significantly $(\mathrm{p}<0.05)$ when compared with normal and normal burned group. While after 30 days a highly significant $(p<0.01)$ increase in their levels were recorded. In contrast, HDL level was significantly decreased after 15 days and was highly significant $(p<0.01)$ decreased after 30 days.

Daily topical treatment with BPF for 15 days had a non significant decrease in serum TGs, T. Cholesterol, LDL and vLDL levels in comparing with the diabetic burned group. While after 30 days, the decrease became significant $(\mathrm{P}<$ 
0.05) in comparing with the comparing with the diabetic burned corresponding diabetic burned group.

Also the increase of HDL level was non significant while the increase became significant $(\mathrm{p}<0.05)$ after 30 days.

Treatment topically and i.p. with $\mathrm{BPF}$ for 15 days had a significant decrease $(p<0.05)$ in serum TGs, T. Cholesterol, LDL and vLDL levels in group. While after 30 days, the decrease became highly significant $(\mathrm{P}<0.01)$ in comparing also with the corresponding diabetic burned group. Also the increase of HDL level after 15 days was significant $(p<0.05)$ while, the increase became highly significant $(\mathrm{p}<0.01)$ after 30 days.

Table 4: Effect of interpretonially (i.p.) and/or topically treatment with bradykinin potentiating factor (BPF) $1 \mu \mathrm{g} / \mathrm{gm}$ isolated from scorpion venom Buthus occitanus within 15 and 30 days on (Chol., TGs, HDL-C, LDL-C and vLDL) of burned skin of alloxan-induced diabetic Guinea pigs.

\begin{tabular}{|c|c|c|c|c|c|}
\hline \multirow{2}{*}{ Groups } & $\begin{array}{l}\text { Cholesterol } \\
(\mathrm{TC}) \mathrm{mg} / \mathrm{dl} \\
\end{array}$ & $\begin{array}{l}\text { HDL } \\
\mathrm{mg} / \mathrm{dl}\end{array}$ & $\begin{array}{l}\text { LDL } \\
\mathrm{mg} / \mathrm{dl}\end{array}$ & $\begin{array}{c}\text { Vldl } \\
\mathrm{mg} / \mathrm{dl}\end{array}$ & $\begin{array}{c}\text { Triglycerides } \\
\text { (TGs) mg/dl } \\
\end{array}$ \\
\hline & Mean \pm S. D. & Mean \pm S.D. & Mean \pm S. D. & Mean \pm S. D & Mean \pm S. D \\
\hline \multicolumn{6}{|c|}{ After 15 days } \\
\hline Normal & $102.0 \pm 5.16$ & $44.33 \pm 0.77$ & $36.8 \pm 1.84$ & $19.5 \pm 1.10$ & $97.7 \pm 6.20$ \\
\hline Normal diabetic & $93.7 \pm 4.7$ & $72.7 \pm 1.06$ & $34.0 \pm 2.37$ & $19.33 \pm 1.03$ & $95.5 \pm 4.07$ \\
\hline $\begin{array}{c}\text { Diabetic burns } \\
\text { (control) }\end{array}$ & $156.0^{+\mathrm{a}} \pm 4.75$ & $24.0^{-\mathrm{a}} \pm 0.67$ & $101.6^{+a} \pm 3.06$ & $30.5^{+a} \pm 1.08$ & $152.0^{+a} \pm 4.7$ \\
\hline $\begin{array}{c}\text { Topical BPF } \\
\text { (Treatment) }\end{array}$ & $150.5 \pm 3.76$ & $25.8 \pm 0.66$ & $95.8 \pm 4.00$ & $29.2 \pm 0.72$ & $146.0 \pm 4.5$ \\
\hline $\begin{array}{c}\text { Topical + i.p. } \\
\text { BPF } \\
\text { (Treatment) }\end{array}$ & $133.0^{b} \pm 3.31$ & $33.6^{\mathbf{b}} \pm 0.82$ & $73.2^{\mathbf{b}} \pm 2.79$ & $26.1^{\mathbf{b}} \pm 0.71$ & $130.7^{\mathrm{b}} \pm 5.9$ \\
\hline \multicolumn{6}{|c|}{ After 30 days } \\
\hline Normal & $92.3 \pm 4.23$ & $46.5 \pm 1.14$ & $40.0 \pm 3.21$ & $20.5 \pm 0.99$ & $102.5 \pm \mathbf{5 . 1 1}$ \\
\hline Normal burned & $100.0 \pm 6.24$ & $44.9 \pm 1.04$ & $36.7 \pm 3.18$ & $21.0 \pm 0.67$ & $106.0 \pm \mathbf{4 . 3 4}$ \\
\hline $\begin{array}{c}\text { Diabetic burns } \\
\text { (control) }\end{array}$ & $178.0^{++a} \pm 3.82$ & $18.7^{-\mathrm{a}} \pm 0.59$ & $191.8^{++a} \pm 4.36$ & $34.2^{++\mathrm{a}} \pm 1.14$ & $170.0^{++\mathbf{a}} \pm 5.13$ \\
\hline $\begin{array}{l}\text { Topical BPF } \\
\text { (Treatment) }\end{array}$ & $140.0^{-\mathbf{b}} \pm 3.31$ & $27.0^{+\mathbf{b}} \pm 0.78$ & $85.4^{-\mathbf{b}} \pm 2.17$ & $27.6^{-\mathbf{b}} \pm 0.77$ & $138.0^{-\mathrm{b}} \pm 3.48$ \\
\hline $\begin{array}{c}\text { Topical + i.p. } \\
\text { BPF } \\
\text { (Treatment) }\end{array}$ & $116.7^{-\mathrm{b}} \pm 4.03$ & $38.0^{++\mathrm{b}} \pm 0.91$ & $54.7^{-\mathrm{b}} \pm 3.45$ & $24.0^{--\mathrm{b}} \pm 1.28$ & $120.0^{-\mathrm{-b}} \pm 4.09$ \\
\hline
\end{tabular}

Results are expressed as mean \pm S.D. of 10 animals.

$+\mathrm{a}=$ significantly increased from normal at $\mathrm{p}<0.05$

$++\mathrm{a}=$ highly significant increased from normal at $\mathrm{p}<0.01$

$-\mathrm{a} \quad=$ significantly decreased from normal at $\mathrm{p}<0.05$

$--\mathrm{a}=$ highly significant decreased from normal at $\mathrm{p}<0.01$

$+\mathrm{b}=$ significantly increased from diabetic burned (control) at $\mathrm{p}<0.05$

$++b=$ highly significant increased from diabetic burned (control) at $\mathrm{p}<0.01$

$-\mathrm{b}=$ significantly decreased from diabetic burned (control) at $\mathrm{p}<0.05$

$--b=$ highly significant decreased from diabetic burned (control) at $\mathrm{p}<0.01$ 


\section{DISCUSSION}

The red blood cells count can be considered as a biological index for the determination of the effect of diabetic anemia. The present study demonstrated that alloxan induced diabetes which resulted in a significant decrease in red blood cells count, hemoglobin and hematocrit when compared with the normal group. The significant decrease of erythrothytic count and blood hemoglobin content in the present study is in the accordance with the finding of (Salman, 2008).

The improvement of RBCs, HB, $\mathrm{PCV}$ and platelets count in the present study after treatment with BPF, are in accordance with finding of (Salman, 2002 and 2009), who showed that injection of BPF in sub-lethally-irradiated and non-irradiated growing guinea pig accelerated the generation of thymus and spleen cellularity and completely recovered.

These observations and investigations were the base for the hypothesized ameliorating activity of BPF in the present study.

Since oxidative damage of tissues is a major pathogenesis of many human diseases including diabetes, this study will summarize the available data which indicated the role of the preventive effect of BPF on the development of burnt wound healing in diabetic animal by mechanisms may include the role of BPF of endogenous antioxidant enzymes of burned animals (Mikrut et al., 2001).

There is the fact that, glucose autooxidation is considered to be a source of free radicals and hydrogen peroxide (Ceriello et al., 1992), These processes could contribute to the elevated levels of plasma peroxide and MDA (Olczyk et al., 1994), and hence these free radical may delay the healing of burned skin. However, BPF injection to the diabetic animals, for 4 weeks, controlled the glucose levels and improved the antioxidant status, which hastened the dermal wound healing process. The mechanisms by which BPF hastened the healing process was Activation of bradykinin and consequently activation of B2R, which results in the formation of nitric oxide (NO), a potent scavenger molecule, which could reduce the accumulation of reactive oxygen species (ROS) (Allard et al., 2007). The other mechanism is the role of BPF in enhancing connective tissue synthesis, cell division and fiber secretion, reepithelilization, prostaglandin $\mathrm{E}_{2}\left(\mathrm{PGE}_{2}\right)$, $\mathrm{NO}$, serotonin, prostacyclin $\mathrm{I}_{2}\left(\mathrm{PGI}_{2}\right)$ production and stimulating chemotaxis as well as healing-inducing inflammation (Salman, 1995; Özotürk, 2001 and Qiu et al., 2002).

It is worth to mention that, in this study, the treatment with BPF was effective in the dermal healing in both cases topical and interperitonial, and that may be sustain, the BPF may be considered potentially in the treatment of severe skin burns.

While diabetes mellitus (DM) is a multifactorial disease which is characterized by hyperglycemia, lipoprotein abnormalities and raised basal metabolic rate (Owu et al., 2006), the present study will summarize the beneficial effects of BPF on the lipid profile of the diabetic burned guinea pigs.

According to (Grover et al., 2000), alloxan causes a massive reduction in insulin release by the destruction of $\beta$ cells of the islets of langerhans, thereby inducing hyperglycemia. Consequently, insulin deficiency leads to various metabolic alterations in the animals as increased blood glucose and increased cholesterol (Shanmugasundaram et al., 1983).

According to (Salman et al., 2002) the nonapeptide bradykinin has a wide range of biological effects on a number of different tissues and organs.

The present study has revealed decreases in serum cholesterol and triglycerides levels in diabetic burned 
guinea pigs following BPF treatment. These findings are in agreement with other investigators who recorded the decrease in serum cholesterol and triglycerides levels envenomated rats was in laboratory animals injected with viper snake venoms. They suggested that, the snake venom might have mobilized the lipids from adipose and other tissues by activation the lipolytic enzymes which could have split tissue lipid with the liberation of free fatty acids (Al-Jammaz, 2002 and Salman, 2010)

\section{REFERENCES}

Abd-El-Raheim, S. A. (1990): Physiological studies of a separated fraction from, the venom of Egyptian scorpion on the living cells of some organs. Ph. D. Thesis Assuit Univ. (Sohag Campus).

Abd-El-Raheim, S. A. (1995): Effect of extracted crude venom of the jelly-fish, Eutonina indicans on kidney function. J. Egypt. Ger. Soc. Zool., 18 (A):131- 147.

Al-Jammaz, I. (2002): Effects of envenomation by Creastes vipera crude venom on plasma and tissue metabolites of rats. Kawait, J. Eng. 29 (1): 111-119.

Allard, J.; Bule'on, M.; Cellier, E.; Renaud, I.; Pecher, C.; Praddaude, F.; Conti, M.; Tack, I. and Girolami, J. (2007): ACE inhibitor reduces growth factor receptor expression and signaling but also albuminuria through B2-kinin glomerular receptor activation in diabetic rats. Am J Physiol Renal Physiol 293: $1083-1092$.

Buschard, K., (1996): Diabetic animal models. APMIS 104 (9): 609-614.

(Review). Chen, D., Wang, M.W., (2005). Development and application of rodent models for type 2 diabetes. Diabet. Obes. Metab. 7 (4):307-317.

Ceriello, A.; Quatraro, A.; Giugliano, D. (1992): New insights on non-

enzymatic glycosylation may lead to therapeutic approaches for the prevention of diabetic complications. Diabetic Med., 9(3): 297-299.

Ferreira, S. H. (1965): A bradykininpotentiating factor (BPF) present in the venom of Bothrops jararaca. Br. J. Pharmac. Chemother., 24: 163 - 169.g

Filippi, C. and Von Herrath, M., (2005): How viral infections affect the autoimmune process leading to type 1 diabetes. Cell Immunol. 233 (2): 125-132.

Fossati, P.; Prencipe, L. and Berti, G. (1980): Use of 3,5-dichloro-2hydroxybenzenesulfonic acid/4aminophenazone chromogenic system in direct enzymic assay of uric acid in serum and urine. Clin. Chem., 26 (2): 227-231.

Grover, J. K.; Vats, V. and Rathi, S. S. (2000): Antihyperglycemic effect of Eugenia jambolana and Tinospora cordifolia in experimental diabetes and their effects on key metabolic enzymes involved in carbohydrate metabolism. J. Ethnopharmacol., 73: 461-470.

Hall, J. M. (1992): Bradykinin receptors: pharmacological properties and

biological roles. Pharmacol. Ther., 56: 131- 190.

Kloppel, G.; Wedekind, D.; Prokop, C.M. and Hedrich, H.J., (2001): The LEW.1AR1/Ztm-iddm rat: a new model of spontaneous insulin dependent diabetes mellitus. Diabetologia 44 (9):1189-1196.

Mikrut, K.; Paluszak, J.; Kozlik, J.; Sosnowski, P.; Krauss, H. and Grzes'kowiak E. (2001): The effect of bradykinin on the oxidative state of rats with acute hyperglycaemia. Diabetes Res. Clin. Pract., 51(2): 79-85.

Morony, M. J. (1963): Facts from figures. Penguim Books Ltd., Harmonds-Worth, Middle sex.

Nassar, A. Y.; Abu-Sinna, G. and AbdEl-Raheim, S. (1990): Effect of a bradykinin potentiating fraction, isolated from venom of the Egyptian scorpion, Buthus occitanus, on the ovaries and endomertrium of mice. Toxicon, 28:525534.

Nishikimi, M.; Appaji, N. and Yogi, K. (1972): The occurrence of superoxide anion in the reaction of reduced phenazine methosulfate and molecular oxygen. Biochem. Bioph. REs. Commun., 46 (2): 849-854.

Ohkawa, H.; Ohishi, N. and Yagi, K. (1979): Assay for lipid peroxides in animal tissues by thiobarbituric acid reaction. Anal Biochem., 95 (2): 351-358.

Olczyk, K.; Kos'cielniak-Kocurek, E.; Sonecki, P. and Zdenkowski, W. (1994): The lipid peroxidation products and the enzymes of antioxidant system in patients with diabetes mellitus. Roczniki Akademii Medycznej w. Bialymstoku, 39: 93-99.

Owu DU, Antai AB, Udofia KH, Obembe AO, Obasi KO, Eteng MU, ( 2006): Vitamin C improves basal metabolic rate and lipid 
profile in alloxan-induced diabetes mellitus in rats, J. Biosciences 31(5): 575-579.

Özotürk, Y. (2001): Kinin receptors and their antagonists as novel therapeutic agents. Curr. Pharm., 7(2): 135 - 161.

Portha, B., Blondel, O., Serradas, P., Mcevoy, R., Giroix, M.H., Kergoat, M., Bailbe, D., (1989): The rat models of non-insulin dependent diabetes induced by neonatal streptozotocin. Diabet. Metab. 15 (2): 6175 (Review).

Qiu, Z.; Liu, Q.; Guo, D. and Fu, X. (2002): The effect of bradykinin B (2) receptor Xi. antagonist on cough reactivity in a sensitized Guinea pig model. Zhonghua, Jie. He. Hu. Za. Zhi., 25 (2) :74 - 77.

Salman, M. M. A. (1995): Effect of a bradykinin potentiating factor isolated from scorpion venom, Buthus occitanus on burnt skin of Guinea pig in comparison with other drugs. M. S. Thesis, Faculty of science, Ain Shams University.

Salman, M. M. A. (2002): Serological, hematological and biochemical studies on bradykinin potentiating factor isolated from scorpion venom. D.Ph. Thesis, Faculty of Science, Ain Shams University.

Salman, M. M. A. (2008): Effect of a bradykinin potentiating factor isolated from scorpion venom on red blood cells indices in alloxan-induced diabetic guinea pigs. $3^{\text {rd }}$ international conference on natural toxins, Cairo-Egypt, 16-18 December 2008.

Salman, M. M. A. (2009): The Ameliorative Effect Of A Single Dose Of A Bradykinin Potentiating Factor Isolated From Scorpion Venom On Red Blood Cells Indices In Alloxan-Induced Diabetic Rats. Egypt. Acad. J. biolog. Sci., 1(1): 33-43

Salman, M. M. A. (2010): The Ameliorative Effect Of A Single Dose Of A Bradykinin Potentiating Factor Isolated From Scorpion Venom On Red Blood Cells Indices In Alloxan-Induced Diabetic Rats.

Shanmugasundaram, K. R.; Panneerselvam, S.P. and hanmugasundaram E. R. B.
(1983): Enzyme changes and glucose utilization in diabetic rabbit,: The effect of Gymnema sylvestrae, R. Br. J. Ethnopharmacol, 7:205-216.

Sharma, V. K.; Kumar, S.; Patel, H. J. and Hugar, S. (2010): Hypoglycemic activity of ficus glomerata in alloxan induced diabetic rats. International J. of Pharmaceutical Sci., 2 (1): 18-22.

Sun, Y.; Ma, X.; Zhou, D.; Vacek, I. and Sun, A.M. (1996): Normalization of diabetes in spontaneously diabetic cynomologus monkeys by xenografts of microencapsulated porcine islets without immunosuppression. J. Clin. Invest. 54 (5): 769-774.

Suryawanshi, N. P.; Bhutey, A. K.; Nagdeote, A. N.; Jadhav, A. A. and Manoorkar, G. S. (2006): Study of lipid peroxide and lipid profile in diabetes mellitus. Indian J. of Clinical Biochem., 21 (1): 126-130.

Trivedi N. A.; Mazumdar B.; Bhatt J. D. and Hemavathi, K. G. (2004): Effect of shilajit on blood glucose and lipid profile in alloxan induced diabetic rats. Department of Pharmacology, Medical College, Baroda - 390001, India.

Wachtfogel, Y. T.; DeLa Cadena, R. A. and Colman, R. W. (1993): Structural biology, cellular interactions and pathophysiology of the contact system. Thromb. Res., 72 (1): $1-21$.

Wachtfogel, Y. T.; Kettner, C.; Hack, C. E.; Nuijens, J. H.; Reilly, T. M.; Knabb, R. M.; Kucich, U.; Niewiarowski, S.; Edmunds, L. H. Jr. and Colman, R.W. (1998): Thrombin and human plasma kallikrein inhibition during simulated extracorporeal circulation block platelet and neutrophil activation. Thromb. Haemost., 80 (4): 686 - 691.

Weiss, H.; Bleich, A.; Hedrich, H.J.; Kolsch, B.; Elsner, M.; Jo rns, A.; Lenzen, S.; Tiedge, M. and Wedekind, D. (2005): Genetic analysis of the LEW.1AR1-iddm rat: an animal model for spontaneous diabetes mellitus. Mamm. Genome 16 (6): 432-441. 


\title{
ARABIC SUMMARY
}

\section{دراسات فسيولوجية على - مستخلص من سم العقرب ـ كعامل منشط للبراديكينين على الحروق الجلاية لخنازير غينيا المصابة بسكر الام المستحدث بوبن مابطة الألوكزان.}

\author{
عبد الرحيم علي الثاطر، محمد محمود سالمان و أسماء فاروق عبد الهادي

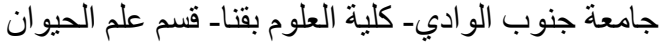

رغم ما هو معروف من التأثير ات السمية لسموم العقارب والثعـابين السـامة، فـإن هناك كثير من الأبحاث الحديثة

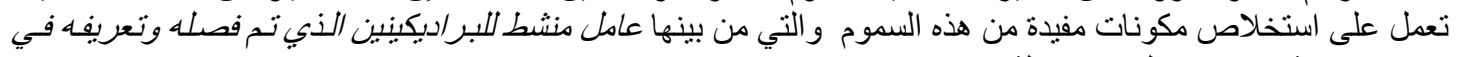

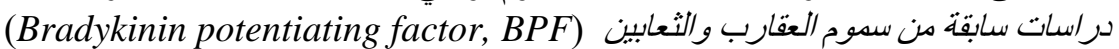

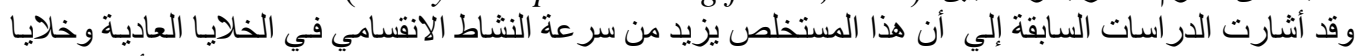

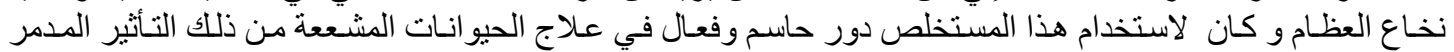

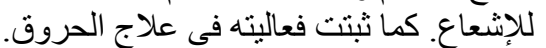

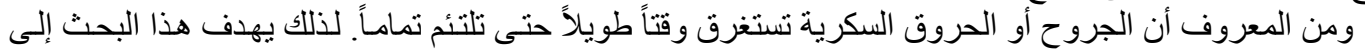
در اسـة تأثير هذا المستخلص (BPF) في علاج حروق الجلد لذكور خنازير غينيا المصسابة بداء السكري المستحدث بو/سطة الألوكزان.

$$
\text { ومن ثم فقد تم تقسيم الحيوانات (خنازير غينيا) إلى أربع مجمو عات : }
$$

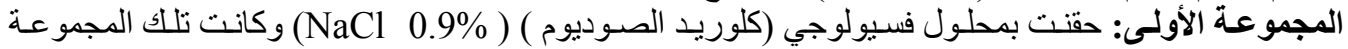

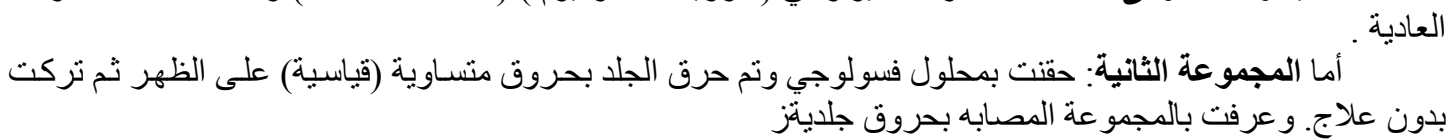

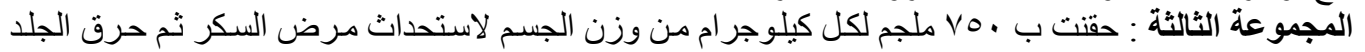

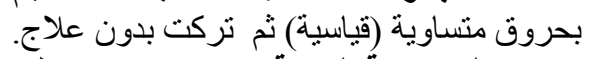

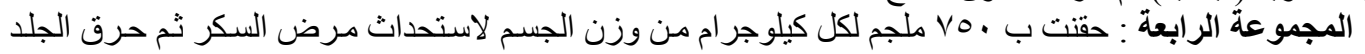

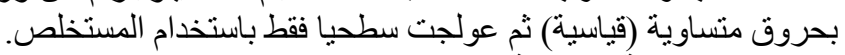

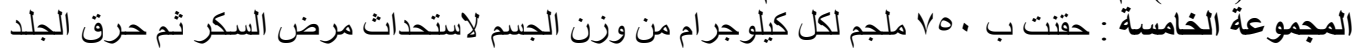

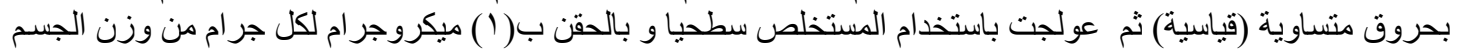
من المستخلص السمي.(في (BPF)

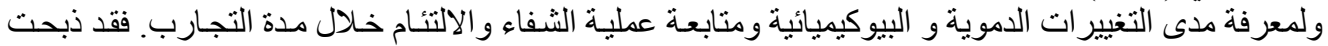

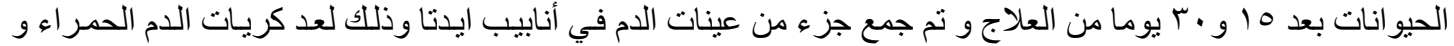

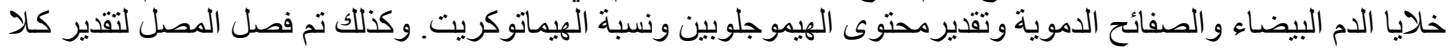

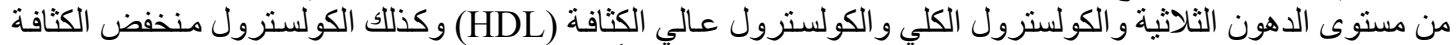

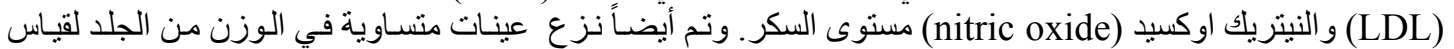

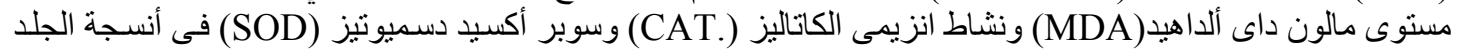
لخنازير غينيا.

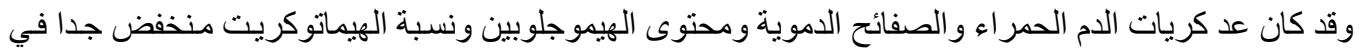

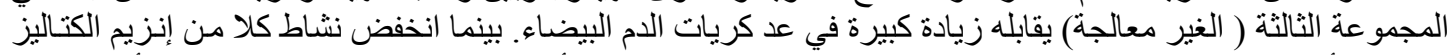

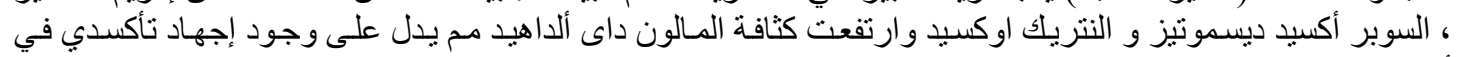

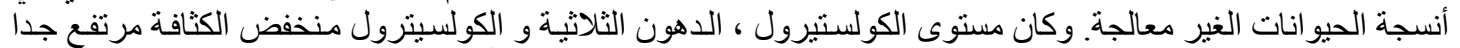

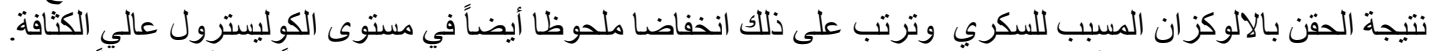

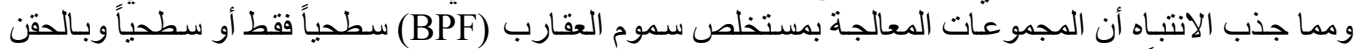

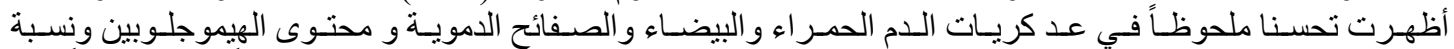

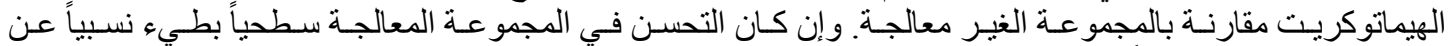

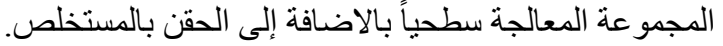

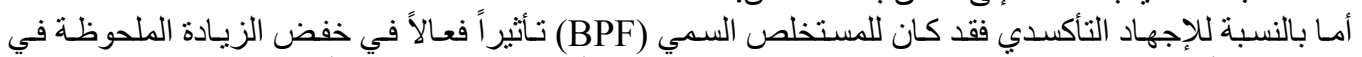

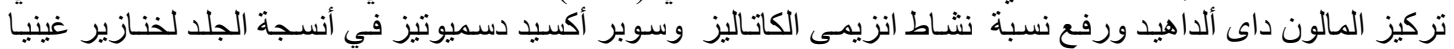

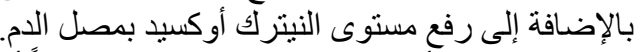

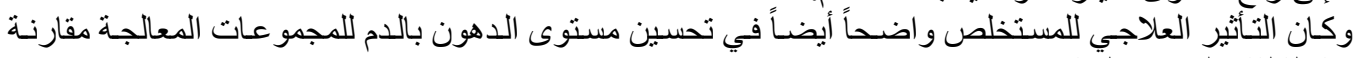
بالمجمو عة الثالثة (الغير معالجة).

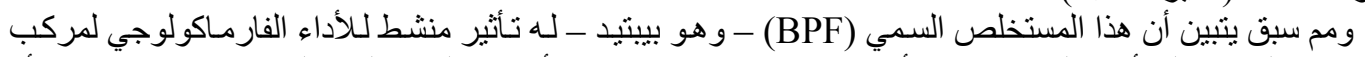

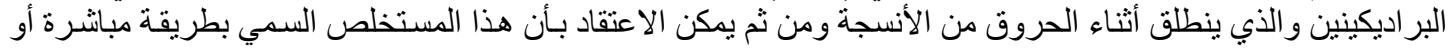
غير مبانشرة ينشطُ عو امل النمو الخلوي في الجلد المحروق للخنازير المصابة بداء السكري ويعجل عملِية الثفاء و الالتئام. 